\title{
Pandemics and communication: an experimental assessment
}

\section{Carolina Melo ${ }^{1}$}

Sandro Cabral 2

1 Insper Institute of Education and Research / PhD Program in Business Economics, São Paulo / SP - Brazil

2 Insper Institute of Education and Research, São Paulo / SP - Brazil

Communication is a key factor in containing a pandemic. Fragmented information may affect people's perceptions and behaviors, especially in times of governmental miscommunication, potentially jeopardizing efforts aimed at containing the spread of the disease. To test whether and how people have been sensitive to broken information during the COVID-19 pandemic in Brazil, we performed a randomized survey experiment on a sample of 571 respondents. We found that more pessimistic or more optimistic fragmented messages about the pandemic have no overall significant average effect on perceptions and planned behavior of the respondents. The exploratory analyses showed that particular sociodemographic groups are more sensitive to these fragmented messages. While less educated people react to more pessimistic messages with an increased likelihood to intensify prevention measures, people aged 60 or older - the high-risk group for COVID-19 complications - react to more optimistic messages with a reduced probability to intensify prevention measures. Besides providing insights to the public administration literature on disaster management, the results reinforce the need for governments to consistently centralize communication efforts to guarantee that people are equipped with complete and accurate information to form their perceptions and adequate their behaviors towards a health crisis.

Keywords: COVID-19; communication; survey experiment.

\section{Pandemias e comunicação: uma avaliação experimental}

$\mathrm{Na}$ tentativa de conter uma pandemia, comunicação pode ser a chave para o sucesso ou para o fracasso. Informações fragmentadas podem afetar as percepções e comportamentos das pessoas, especialmente em tempos de má comunicação governamental, potencialmente minando os seus esforços colaborativos para impedir a disseminação da doença. Para testar se e como as pessoas se apresentam sensíveis a informações quebradas durante a pandemia da COVID-19 no Brasil, usamos um experimento aleatório junto a 571 respondentes. Nossos resultados apontam que mensagens quebradas, mais pessimistas ou mais otimistas, com relação à pandemia não têm um efeito médio significante nas percepções e comportamentos planejados dos respondentes. Numa análise mais exploratória, no entanto, nossos resultados mostram que certos grupos sociodemográficos são mais sensíveis a tais informações quebradas. Enquanto pessoas com baixo nível de escolaridade reagem a mensagens mais pessimistas com um aumento na chance de elas intensificarem medidas de prevenção, pessoas mais velhas (com 60 anos ou mais) - que compõem o grupo de risco para complicações decorrentes do novo coronavírus - reagem a mensagens mais otimistas com uma grande redução na chance de elas intensificarem medidas de prevenção. Além de contribuir com a literatura de gestão de desastres, nosso trabalho reforça a necessidade de governos centralizarem esforços de comunicação, de forma a garantir que as pessoas estejam munidas com informações completas e precisas para formarem suas percepções e adequarem seus comportamentos a uma crise de saúde pública.

Palavras-chave: COVID-19; comunicação; experimento aleatório. 


\section{Pandemias y comunicación: una evaluación experimental}

En un intento por contener una pandemia, la comunicación puede ser la clave del éxito o el fracaso. La información fragmentada puede afectar las percepciones y los comportamientos de las personas, especialmente en tiempos de mala comunicación del gobierno, lo que puede socavar sus esfuerzos de colaboración para prevenir la propagación de la enfermedad. Para testar si las personas son sensibles a la información fragmentada durante la pandemia de COVID-19 en Brasil, utilizamos un experimento aleatorio con 571 encuestados. Nuestros resultados indican que los mensajes rotos, más pesimistas o más optimistas, con respecto a la pandemia no tienen un efecto medio significativo en las percepciones y los comportamientos planificados de los encuestados. Sin embargo, en un análisis más exploratorio, nuestros resultados muestran que ciertos grupos sociodemográficos son más sensibles a dicha información fragmentada. Mientras que las personas con un bajo nivel de educación reaccionan a mensajes más pesimistas con una mayor probabilidad de intensificar las medidas preventivas, las personas mayores (de 60 años o más), que conforman el grupo riesgo de complicaciones resultantes del nuevo coronavirus, reaccionan a mensajes más optimistas con una gran reducción en la posibilidad de que intensifiquen las medidas preventivas. Además de contribuir a la literatura sobre gestión de desastres, nuestro trabajo refuerza la necesidad de que los gobiernos centralicen los esfuerzos de comunicación para garantizar que las personas reciban información completa y precisa para formar sus percepciones y adaptar sus comportamientos a una crisis de salud pública.

Palabras clave: COVID-19; comunicación; experimento aleatorio.

\section{BACKGROUND}

The COVID-19 pandemic has emerged as one of the most severe global crises ever seen in history. Billions of people are confined, the virus is unknown, and socioeconomic consequences are unpredictable. Governments around the globe have been following World Health Organization (WHO)'s advice and other evidence-based recommendations to promote strict social distancing measures. Nevertheless, some voices have opposed the scientific evidence and argued that the situation is not that worrying. The Brazilian President, Mr. Bolsonaro, even declared that social isolation is an exaggeration and might harm the population harder - due to negative economic impacts.

Although much is unknown about the epidemiology of the new coronavirus, there is evidence that national policies aimed at mitigating and suppressing its transmission prevent health systems from being rapidly overwhelmed and expressively reduce mortality (Anderson, Heesterbeek, Klinkenberg, \& Hollingsworth, 2020; Walker et al., 2020). Furthermore, despite consequent potential economic losses, early non-pharmaceutical interventions - such as social isolation, quarantine, and social distancing measures ${ }^{1}$ - are shown to have positive effects on economic growth after a pandemic, contributing to faster economic recovery (Correia, Luck, \& Verner, 2020). Hence, preventing an economic slowdown in the early stages of a pandemic may cost a much greater economic loss later, on top of the loss of many lives.

As a complement to capabilities of enforcement - that can ensure confinement through penalties and other coercive measures -, and similar to other policies for which results are determined by citizen participation (Bovaid, 2007), comprehensive actions aimed at containing the spread of a contagious

\footnotetext{
${ }^{1}$ Although we recognize the differences between these non-pharmaceutical interventions, we use the term "social isolation" in the survey experiment described in the paper to refer to any kind of more strict social distancing measure.
} 
disease must count on cooperation of the population to coproduce desired outcomes (Anderson et al., 2020). In the context of a public health response, for cooperation to be successful, previous research has indicated that a well-designed communication strategy must be in place (Clark, Brudney, \& Jang, 2013). Government agencies of all jurisdiction levels must be aligned and come together (Comfort, Waugh, \& Cigler, 2012) to proactively communicate "what is known, what is unknown, and what is being done to get more information" (World Health Organization [WHO], 2020), fostering trust and maintaining a solid reputation. If, instead, people are left to process an excessive amount of broken and incomplete information from different sources - e.g., television shows, newspapers, and social media - on their own, they may reach incoherent conclusions about facts, potentially decreasing the probability that official health advice will be followed and resulting in further disease spread (World Health Organization, 2020; McLennan, 2018).

In Brazil, there have been inconsistencies among communication strategies at different levels of the government. While governments at city- and state-levels have been strongly promoting social distancing and lockdown measures in accordance with experts' recommendations, the initial reaction of the Brazilian president conflicted with established knowledge in pandemic management. The president used national broadcast platforms to state that social isolation is an exaggeration, that the disease is not so dangerous (e.g. a mild flu), and that economic activities cannot stop. As widely covered by the professional press (Coletta, 2020), the presidential address astonished the international community because of the negative spillovers it might engender ${ }^{2}$.

We suppose that these inconsistencies have been making the Brazilian population very confused and sensitive to the different pieces of information they receive, potentially resulting in perceptions and behaviors that may impede an effective containment of the virus dissemination. To verify whether Brazilian people have been sensitive to fragmented messages about the pandemic, we perform a randomized survey experiment, using official information from the WHO to employ two different treatments. Treatment 1 consists of providing survey respondents with a more pessimistic message regarding the pandemic, one that says that fatality rates can be higher in some affected countries. Treatment 2, on the other hand, consists of providing respondents with a more optimistic message, saying that fatality rates can be lower in some affected countries. If assigned to the control group, respondents receive a general message about the COVID-19 pandemic. We then check average treatment effects on respondents' perception of how worrying the national epidemic ${ }^{3}$ is, on respondents' perception of whether social distancing measures being taken are exaggerated, and on their plans to intensify preventive measures in the coming days.

Naturally, it is expected that, if respondents are sensitive to broken pieces of information, a more pessimistic message will increase the level of how worrying they perceive the national epidemic

\footnotetext{
${ }^{2}$ In fact, other researchers have also used an experimental approach to show how communication can affect people's perceptions and behaviors. Bursztyn, Egorov, and Fiorin (2020) show that the discourse of public figures can shape social norms. Gross (2008) shows that the framing of a message can affect emotional response and, consequently, the policy opinion of people. And Chong, and Druckman (2010) show that, although conflicting messages can nullify one another when received at the same time, when faced with a sequence of messages over time, people tend to give more weight to the messages received more recently.

${ }^{3}$ We use the term "national epidemic" throughout the paper to refer specifically to the new coronavirus widespread occurrence within the country in which we ran the survey - Brazil.
} 
to be, reduce the probability that they find isolation measures an exaggeration, and increase the probability that they plan to intensify prevention measures in a critical period of the national epidemic. Conversely, a more optimistic message will decrease the level of how worrying they perceive the national epidemic to be, increase the probability that they find isolation measures an exaggeration, and decrease the probability that they plan to intensify prevention measures when it is most needed.

In addition to our analyses using the whole survey sample, we also run exploratory analyses to assess how treatments affect different groups of age, gender, education levels, and income levels.

Results show that more pessimistic or more optimistic fragmented messages have no overall significant average effect on perceptions and planned behavior of respondents; suggesting that, on average, they are not sensitive to broken pieces of information with which they are presented. These results indicate that Brazilian adults, with a sociodemographic profile similar to that of the average survey respondent, tend to stick to their perceptions and attitudes towards a national epidemic even when the government, at different levels, fail to provide consistent and complete information to the population.

However, in rather exploratory analyses, we find different results for specific sociodemographic groups. Respondents that do not hold undergraduate or graduate degrees - the least educated people in our sample - react to a more pessimistic message with a higher probability of planning to intensify prevention measures in coming days. And, for the group of high-risk for COVID-19 complications - people aged 60 or older (Chaomin Wu et al., 2020; Onder, Rezza, \& Brusaferro, 2020) -, a more optimistic message regarding the pandemic causes a substantial reduction in one's probability to plan intensifying prevention measures, potentially leading to more older people being infected and seeking medical care ${ }^{4}$. It turns out that a simple more optimistic message, provided to a group of particularly sensitive people, could be the cause of having the health system saturated.

Our results are valuable to inform policymakers interested in designing effective communication strategies to contain the spread of the virus and to scholars interested in the theoretical aspects of public emergencies, including collaborative efforts (Kapucu \& Garayev, 2011), institutional design (Boin \& Lodge, 2016), supply chain management (Shareef et al., 2019), among others.

\section{DATA AND METHODS}

On March 24 of 2020, the Brazilian president, Mr. Bolsonaro delivered a national speech to all Brazilians opposing strict social distancing measures and undermining the severity of the pandemic, going against the sayings of health authorities. In an attempt to capture how fragmented pieces of information can shape citizen perceptions and potential attitudes towards the national epidemic, especially in times of governmental miscommunication, we employ an experimental approach.

\footnotetext{
${ }^{4}$ An increase in the number of people aged 60 or older seeking medical care can be particularly dangerous, because these people are more likely to need intensive care, contributing to the exceeding of inpatient care capacity in health units.
} 
We used an online survey platform to both collect data and randomly assign participants to control and treatment groups, ensuring our experimental design ${ }^{5}$. We ran a survey starting in the morning of March 26 and ending in the morning of March 28 of 2020, but all responses - except for one - were registered either on March 26 or March $27^{6}$. Residents of all Brazilian states, aged 18 or older, were welcome to answer the survey upon agreement to have their anonymous results used for research purposes, thus allowing us to obtain 571 complete responses ${ }^{7}$.

The survey was available in Portuguese and was divided in three parts. In the first part, respondents were asked questions regarding their profile, allowing us to collect data on sociodemographic variables, such as age, gender, race, education level, and household income level (class AB or class CDE). In the second part, respondents were randomly assigned to one of three groups: control group, treatment group 1, or treatment group 2; and, depending on the group to which the respondent was assigned, he/she received a different piece of information regarding the COVID-19 pandemic. Finally, in the third part of the survey, respondents were asked questions about their perceptions and planned behavior regarding the national epidemic.

On one hand, the control group received a general message (in Portuguese) about the pandemic, saying: Now, let us talk specifically about the coronavirus pandemic. According to the World Health Organization (WHO) dashboard ${ }^{8}$, and considering data available on March 25 of 2020, the virus has already reached 196 countries and its fatality rate is $4.46 \%$. However, this rate can vary a lot across countries. On the other hand, the treatment groups received either a more pessimistic or a more optimistic message regarding the pandemic. Treatment group 1 received the same general message that the control group did, but with an additional passage saying: In Italy and Spain, for instance, the fatality rate is higher. In Italy, it is $9.86 \%$ and, in Spain, it is 6.79\%. And treatment group 2 received the same general message that the control group did, but with an additional passage saying: In Norway and Australia, for instance, the fatality rate is lower. In Norway, it is $0.39 \%$ and, in Australia, it is $0.33 \%$. We provided no information about transmission containment measures taken by these countries, when measures were adopted, the countries' sociodemographic profiles, and the intensity of actually testing the population for the presence of the virus. So, the information provided to survey respondents can be considered rather incomplete and fragmented, open to a variety of processing approaches.

After receiving one of the three different messages described above, the respondent were asked three questions: (1) In a scale from 0 to 10, how worrying do you consider the coronavirus epidemic in Brazil?; (2) Do you consider the social isolation measures that are being taken an exaggeration

\footnotetext{
${ }^{5}$ Even though external validity is harmed due to the absence of random sampling, internal validity is guaranteed due to the unbiased random assignment performed within the survey platform.

${ }^{6}$ The idea was to capture a moment during the national epidemic in which citizens could be truly confused and sensitive, due to the conflicting presidential speech.

${ }^{7}$ The survey was distributed through an anonymous link in social media platforms. Brazilian residents were invited to volunteer as respondents. After clicking on the survey link, volunteers were informed that survey participants were not going to be identified and results were going to be exclusively used for research purposes. Then, if they agreed with these terms, volunteers were invited to click on the "next" button to start responding to survey questions.

${ }^{8}$ Retrieved from https://covid19.who.int/
} 
(yes/no)?; and (3) Specialists say that the epidemic in Brazil will get worse before getting better. Do you plan to intensify your prevention measures in the coming days to help contain the epidemic (yes/no)?

These questions allowed us to collect data on three outcome variables of interest:

- Worrying: a variable that can take values from 0 to 10 , depending on how the respondent considers the national epidemic to be worrying, where 0 means that he/she considers it to be not worrying at all and 10 means that he/she considers it to be extremely worrying;

- Exaggerating: a binary variable that takes the value of 1 if the respondent thinks that social isolation measures that are being taken are an exaggeration and 0 otherwise; and

- Intensify: a binary variable that takes the value of 1 if the respondent plans to intensify his/her prevention measures in the coming days to help contain the national epidemic and 0 otherwise.

Among the 571 respondents, 190 were randomly assigned to the control group, 190 were randomly assigned to the treatment group 1 (the group that received a more pessimistic message), and 191 were randomly assigned to treatment group 2 (the group that received a more optimistic message). Table 1 presents summary statistics of all variables contained in our final dataset for all groups combined, and Table A1 - in the appendix - presents summary statistics of all variables by group 9 . As one can note, the average respondent is 41 years old and has an $83 \%$ probability of being aged less than 60 . In addition, the average survey respondent has a $70 \%$ chance of being a female, a $69 \%$ chance of being white, a $79 \%$ chance of holding an undergraduate or graduate degree, and a $29 \%$ chance of being in income classes A or B - classes of the highest income levels in the country. Moreover, one can also note that the baseline level of how worrying respondents from all three groups rate the national epidemic is very high, at about 8.4 in a scale from 0 to 10 ; the baseline percentage of respondents that find isolation measures an exaggeration is low, at about $22 \%$; and the baseline percentage of respondents that plan to intensify prevention measures in coming days is very high, at about $92 \%$. These extreme baseline levels of outcome variables suggest that the average respondent gives little room for becoming more worried about the national epidemic, for becoming less likely to judging isolation measures an exaggeration, and for becoming more likely to planning the intensification of prevention measures.

\footnotetext{
${ }^{9}$ Note that, in order not to prevent respondents from continuing answering questions until the end of the survey, in the question related to income levels, we presented an alternative answer choice that reads: I do not know my family income level or I do not want to report $i t$. Therefore, the number of observations related to the income-level variable is lower than the number of observations related to the other variables.
} 
RAP | Pandemics and communication: an experimental assessment

\section{TABLE 1 SUMMARY STATISTICS}

\begin{tabular}{lccccc}
\hline Variable & Mean & SD & Min & Max & Obs \\
\hline Worrying & 8.4816 & 1.8546 & 0 & 10 & 571 \\
\hline Exaggerating & 0.2137 & 0.4102 & 0 & 1 & 571 \\
\hline Intensify & 0.9019 & 0.2977 & 0 & 1 & 571 \\
\hline Age & 41.4011 & 15.2853 & 18 & 84 & 571 \\
\hline 60+ years & 0.1646 & 0.3712 & 0 & 1 & 571 \\
\hline Female & 0.697 & 0.4599 & 0 & 1 & 571 \\
\hline White & 0.6935 & 0.4614 & 0 & 1 & 571 \\
\hline Black & 0.0473 & 0.2124 & 0 & 1 & 571 \\
Asian & 0.0263 & 0.1601 & 0 & 1 & 571 \\
\hline Brown & 0.2207 & 0.4151 & 0 & 1 & 571 \\
\hline Indigenous & 0.0018 & 0.0418 & 0 & 1 & 571 \\
\hline Primary School & 0.007 & 0.0835 & 0 & 1 & 571 \\
\hline High School & 0.1996 & 0.4001 & 0 & 1 & 571 \\
\hline Undergraduate & 0.3608 & 0.4806 & 0 & 1 & 571 \\
\hline Graduate & 0.4326 & 0.4959 & 0 & 1 & 571 \\
\hline Classes AB & 0.2901 & 0.4542 & 0 & 1 & 524 \\
\hline
\end{tabular}

Source: Elaborated by the authors.

To assess the effect of the two treatments on our outcome variables of interest, we estimate the following regression equation:

$$
Y_{i}=\beta_{0}+\beta_{1} \text { treat }_{i}+\beta_{2} \text { treat }_{i}+u_{i}
$$

where: $Y_{i}$ is the outcome of individual $i$; treat $1_{i}$ is a dummy variable that takes the value of 1 if individual $i$ is in treatment group 1 - that is, if individual $i$ was assigned to receive a more pessimistic message and the value of 0 otherwise; treat $2_{i}$ is a dummy variable that takes the value of 1 if individual $i$ is in treatment group 2 - that is, if individual $i$ was assigned to receive a more optimistic message - and the value of 0 otherwise; and $u_{i}$ is the robust error term for individual $i$. We are interested in $\beta_{1}$ and $\beta_{2}$, since they represent the effect of treatment 1 and the effect of treatment 2 respectively.

Moreover, to assess the heterogeneous effect of the two treatments for different sociodemographic groups, we estimate the following regression equation: 


$$
\begin{gathered}
\text { RAP } \mid \text { Pandemics and communication: an experimental assessment } \\
Y_{i}=\alpha_{0}+\alpha_{1} \text { treat }_{i}+\alpha_{2} \text { treat }_{i}+\alpha_{3} g_{i}+\alpha_{4}\left(g_{i} * \text { treat } 1_{i}\right)+\alpha_{5}\left(g_{i} * \text { treat } 2_{i}\right)+v_{i}
\end{gathered}
$$

where: $Y_{i}$ is the outcome of individual $i$; treat $1_{i}$ is a dummy variable that takes the value of 1 if individual $i$ is in treatment group 1 - that is, if individual $i$ was assigned to receive a more pessimistic message - and the value of 0 otherwise ; treat ${ }_{i}$ is a dummy variable that takes the value of 1 if individual $i$ is in treatment group 2 - that is, if individual $i$ was assigned to receive a more optimistic message - and the value of 0 otherwise; $g_{i}$ is a dummy variable that takes the value of 1 if individual $i$ is in demographic group $g$ and the value of 0 otherwise; $g_{i}{ }^{*}$ treat $1_{i}$ and $g_{i}{ }^{*}$ treat $2_{i}$ are interaction terms; and $v_{i}$ is the robust error term for individual $i$. Now, we are interested in $\alpha_{4}$ and $\alpha_{5}$, since they let us assess how treatment effects change when individual $i$ belongs to demographic group $g$.

It is expected that, if respondents are actually sensitive to broken pieces of information, they will react to the more pessimistic message by perceiving the national epidemic as more worrying, by reducing their likelihood of finding isolation measures an exaggeration, and by increasing their likelihood of planning to intensify prevention measures when critical times are to come. Contrariwise, it is expected that they will react to the more optimistic message by perceiving the national epidemic as less worrying, by increasing their likelihood of finding isolation measures an exaggeration, and by reducing their likelihood of planning to intensify preventive actions in the coming days.

The main identification assumption regarding our empirical strategy lies in the exogeneity of the treatment variables. That is, we assume that treatment 1 and treatment 2 are not correlated with any other factors that determine the outcomes of interest. If randomization was properly conducted, then this condition should be satisfied. We test whether treatment variables are exogenous by (1) running balance tests and (2) including sociodemographic variables as controls in our main regressions and checking whether point estimates change significantly.

Balance test results are presented in Table A2 (see appendix). As one can note, treatment group 1 - the group assigned to receive a more pessimistic message - and treatment group 2 - the group assigned to receive a more optimistic message - are very similar to the control group, on average. No significant differences are found when we compare treatment group 1 with the control group. We find, however, that the proportion of respondents that completed high school and the proportion of respondents that completed a graduate degree from treatment group 2 is significantly different from the proportion of respondents that completed high school and the proportion of respondents that completed a graduate degree from the control group. To investigate if these differences showed up by chance or if they can actually represent a threat to the internal validity of our study, we run our main regressions with and without controls and check whether coefficients change significantly. As it turns out, coefficients of interest remain very robust when we control for sociodemographic variables - see Table 2 and Tables A3 and A4 in the appendix.

\section{MAIN FINDINGS}

Regarding results obtained from estimating regression equation (1), our main finding lies in the fact that, when we consider all survey respondents, both a fragmented pessimistic message and a fragmented optimistic message have no significant average effect on the outcome variables - see Table 2. This finding suggests that people with a profile like that of an average survey respondent are 
not sensitive to broken pieces of information during the COVID-19 pandemic. That is, these people do not react to fragmented messages by changing their perceptions and planned behavior towards the national epidemic ${ }^{10}$.

\section{TABLE 2 TREATMENT EFFECTS (WHOLE SAMPLE)}

\begin{tabular}{lcccccc} 
& $(\mathbf{1})$ & $(\mathbf{2})$ & $(\mathbf{3})$ & $(\mathbf{4})$ & $(5)$ & $(6)$ \\
Variable & Worrying & Worrying & Exaggerating & Exaggerating & Intensify & Intensify \\
\hline Treat 1 & 0.0579 & 0.1712 & 0.0053 & 0.0035 & 0.0000 & 0.0111 \\
SE & 0.1952 & 0.1934 & 0.0425 & 0.0431 & 0.0286 & 0.0308 \\
p-value & 0.7669 & 0.3765 & 0.9015 & 0.9357 & 1.0000 & 0.7195 \\
Treat 2 & 0.0290 & -0.0629 & -0.0116 & 0.0004 & -0.0414 & -0.0359 \\
SE & 0.1884 & 0.1968 & 0.0418 & 0.0427 & 0.0314 & 0.0341 \\
p-value & 0.8775 & 0.7496 & 0.7817 & 0.9928 & 0.1875 & 0.2932 \\
Constant & 8.4526 & 10.2929 & 0.2158 & 1.4218 & 0.9158 & 0.0658 \\
SE & 0.1385 & 0.6828 & 0.0299 & 0.2688 & 0.0202 & 0.1459 \\
p-value & 0.0000 & 0.0000 & 0.0000 & 0.0000 & 0.0000 & 0.6519 \\
N & 571 & 524 & 571 & 524 & 571 & 524 \\
Controls & NO & YES & NO & YES & NO & YES
\end{tabular}

Notes. Estimations performed using regression equation (1). Set of control variables include all sociodemographic characteristics collected in the survey. Standard errors are robust.

Source: Elaborated by the authors.

With regards to public policy, this finding can be both beneficial and detrimental. On one hand, if people act according to the best evidence-based recommendations during the crisis and they stick to their perceptions and behaviors despite exposure to conflicting information provided by government officers, then the country is more likely to be successful in containing virus spread. On the other hand, if people act in discordance with evidence-based recommendations, then the nation is very unlikely to be successful in containing the epidemic. Furthermore, if this is the case and if the government happens to finally come up with a consistent and solid communication strategy to fight the health crisis, then these people will probably not react to the new instructions, making it very difficult for authorities to mobilize the collaborative efforts required for overcoming disease spread.

When we turn to exploratory analyses, aiming at assessing whether and how the more pessimistic and the more optimistic messages affect different sociodemographic groups, we mostly find results

\footnotetext{
${ }^{10}$ It is worth noting that this average non-significant effect may be, at least in part, due to the extreme baseline levels of the outcome variables, as described in the previous section.
} 
that are consistent with our overall non-significant average effects - see Tables A1, A2, A3, and A4 in the appendix. None of the two treatments significantly affect the perceptions of respondents from different sociodemographic groups regarding how worrying the national epidemic is and whether isolation measures are exaggerated. However, interesting effects show up for the probability that one plans to intensify preventive measures in the coming days - see Figures 1 and 2, and Tables A3 and A4 in the appendix.

Results obtained from estimating regression equation (1) for a sample restricted to respondents that hold up to a high school degree show that a more pessimistic message causes an increase of 8.33 percentage points in the probability that one plans to intensify preventive measures in the coming days - this result is statistically significant at the $5 \%$ level $(\mathrm{p}$-value $=0.0414)$. Given that the average person that holds up to a high school degree from the control group has a $91.67 \%$ probability of planning to intensify preventive measures in the coming days, this effect is sufficient to take the probability of people who were assigned to receive a more pessimistic message to $100 \%$. This finding suggests that people with lower levels of education are very sensitive to a more pessimistic message regarding the pandemic. In fact, it takes only a simple piece of more pessimistic information - or a simple piece of more realistic information - to have everyone from the low-education sociodemographic group engaged in complying with intensified prevention measures.

For people aged 60 or older, a more optimistic message causes a decrease of 25.66 percentage points in the probability that one plans to intensify preventive measures in the coming days and this result is statistically significant at the $5 \%$ level ( $\mathrm{p}$-value $=0.014$ ). While the average elderly from the control group has a $91.18 \%$ probability of planning to intensify preventive measures in the coming days, the average elderly who was assigned to receive a more optimistic message has only a $65.52 \%$ probability of doing so. This effect is of a shockingly high magnitude and, because it involves the group of high-risk for COVID-19 complications, it is particularly important to inform policymakers. We are, here, basically saying that a simple more optimistic message can cause sensitive people from the group that carries the highest risk of severe complications not to intensify preventive measures when the epidemic in Brazil is about to go through its period of highest transmission rates.

As for results obtained from estimating regression equation (2), we find that the effect of a more pessimistic message on the probability that one plans to intensify preventive actions is different for people who hold higher levels of education (undergraduate or graduate degrees) and for people who hold lower levels of education (up to a high school degree) - see Figure 3 and Table A5. The effect of a more pessimistic message for people that hold higher levels of education is 10.55 percentage points lower than it is for people that hold lower levels of education, and this result is significant at the $5 \%$ level ( $\mathrm{p}$-value $=0.0467$ ). While the marginal effect of a more pessimistic message for people with lower education levels is 8.33 percentage points, it is -2.22 percentage points for people with higher education levels. These results, in combination with those found through the estimation of equation (1), say that, although both groups have a high baseline probability of planning to intensify preventive measures in coming days, people with lower levels of education are more sensitive and present more room for behavior change, while people with higher levels of education are less sensitive and stick to their initially planned behavior. 


\section{FIGURE 1 EFFECT OF TREATMENT 1 ON INTENSIFY}

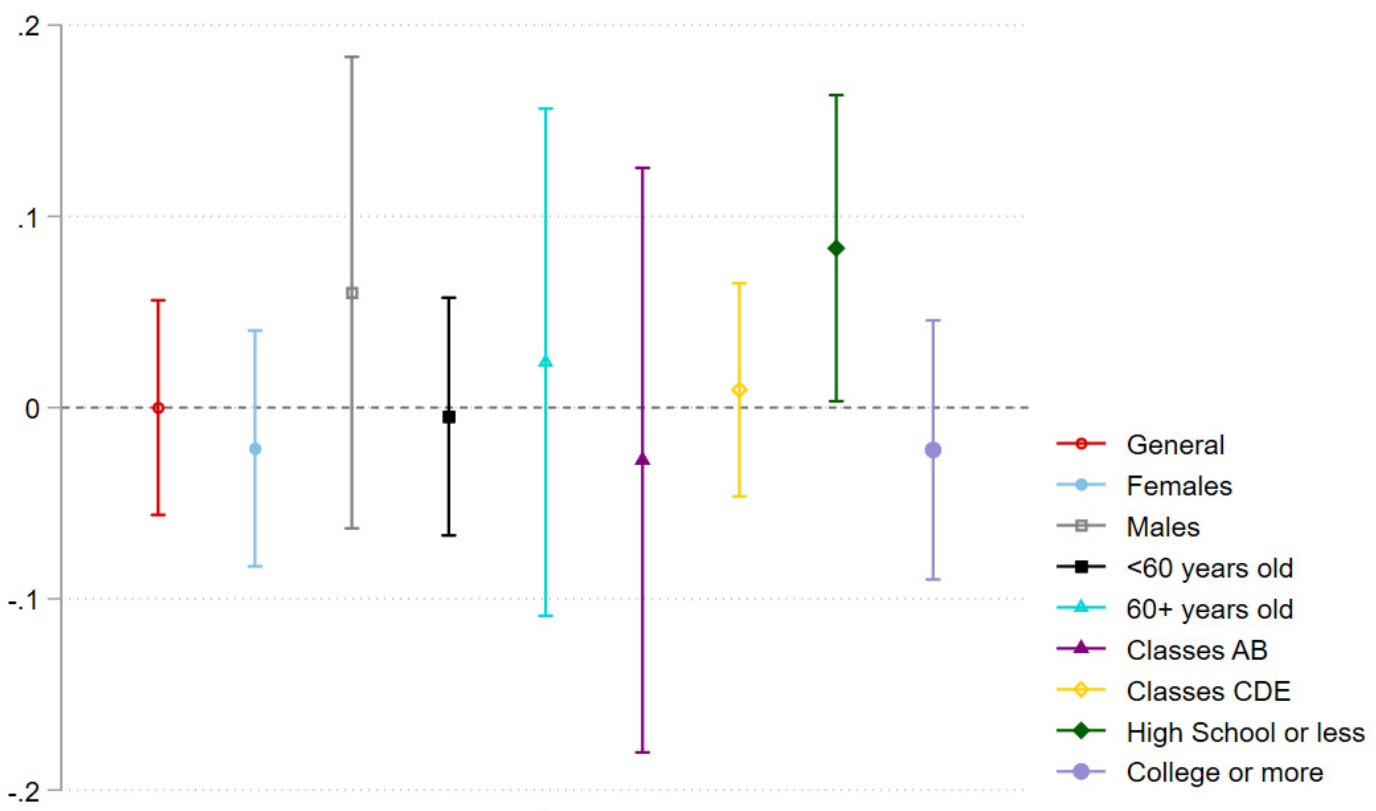

Treatment 1

Notes. The figure shows point estimates and $95 \%$ confidence intervals. The term "general" indicates the point estimate for the unrestricted sample. Source: Elaborated by the authors.

\section{FIGURE 2 EFFECT OF TREATMENT 2 ON INTENSIFY}

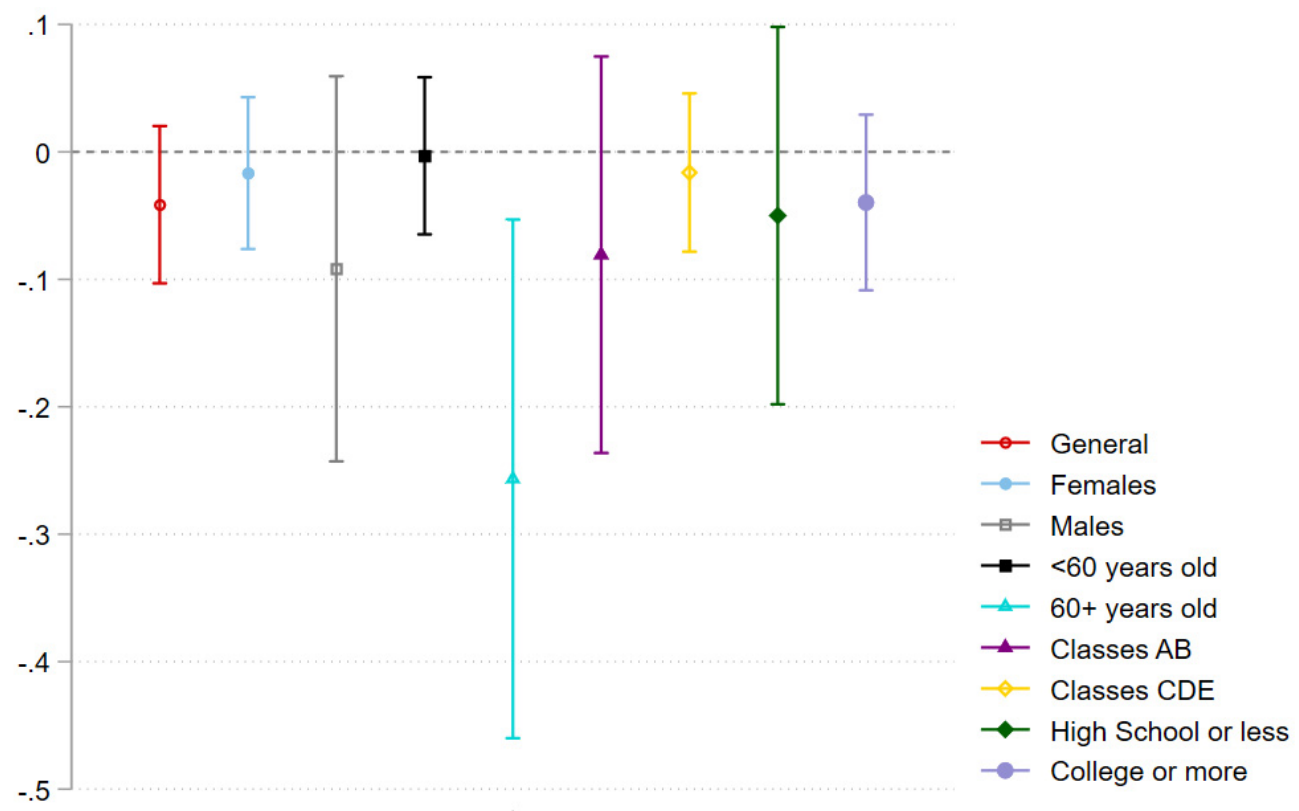

Treatment 2

Notes. The figure shows point estimates and $95 \%$ confidence intervals. The term "general" indicates the point estimate for the unrestricted sample. Source: Elaborated by the authors. 
Finally, with the estimation of equation (2), we also find that the effect of a more optimistic message on the probability of intensifying prevention measures is 25.35 percentage points lower for people aged 60 or older ( $\mathrm{p}$-value $=0.0172$ ) - see Figure 4 and Table A6. In fact, the marginal effect of such more optimistic message for younger people is only -0.31 percentage point, whereas the effect of such more optimistic message for older people is -25.66 percentage points. The combination of these results with those obtained from the estimation of regression equation (1) says that, on average, older people give up on intensifying preventive measures when presented with a more optimistic message. Younger people, however, stick to their behavior when presented with the more optimistic facts.

\section{FIGURE 3 HETEROGENEOUS EFFECTS OF TREATMENT 1 ON INTENSIFY}

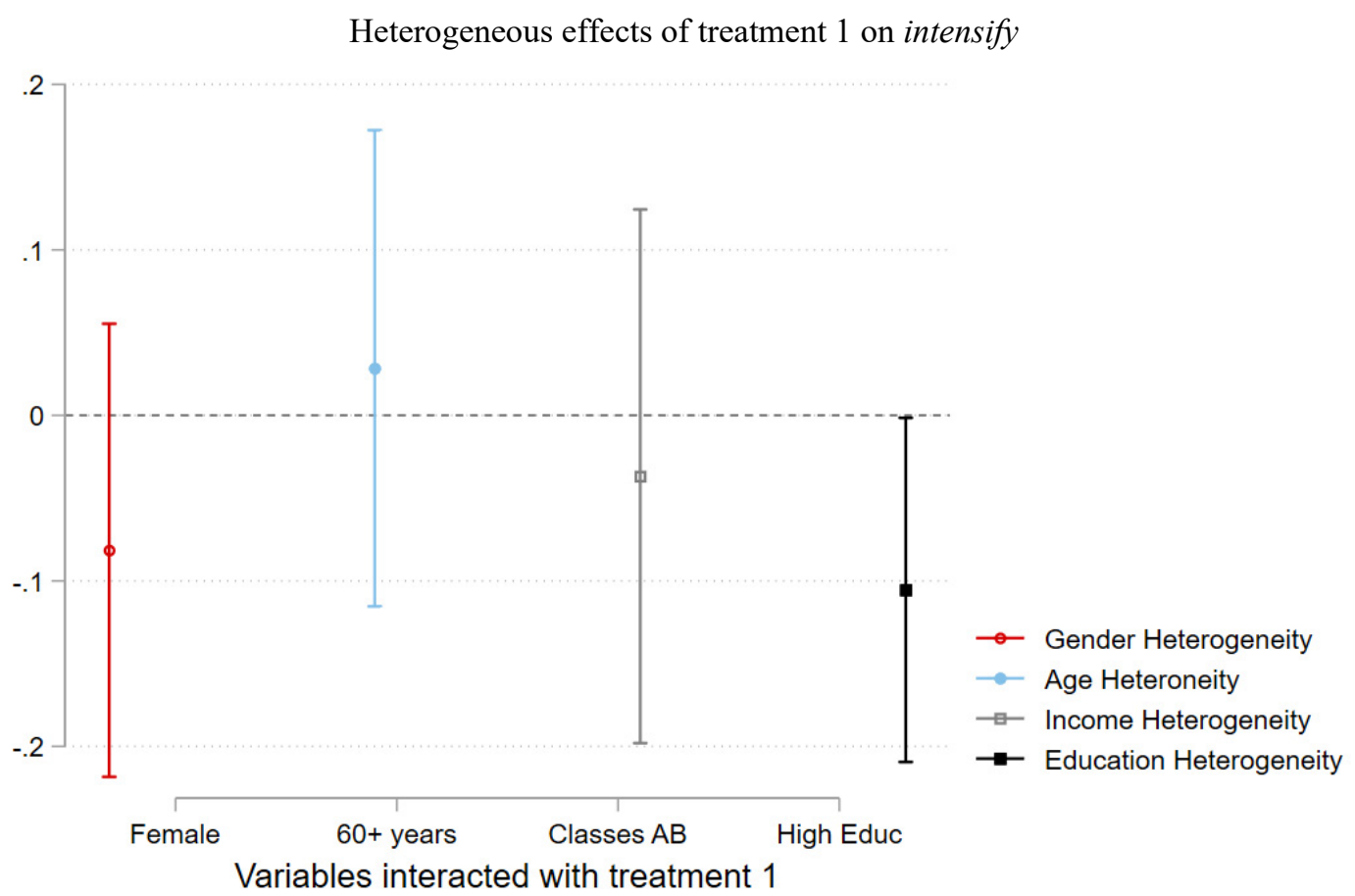

Notes. The figure shows point estimates and 95\% confidence intervals. Source: Elaborated by the authors. 


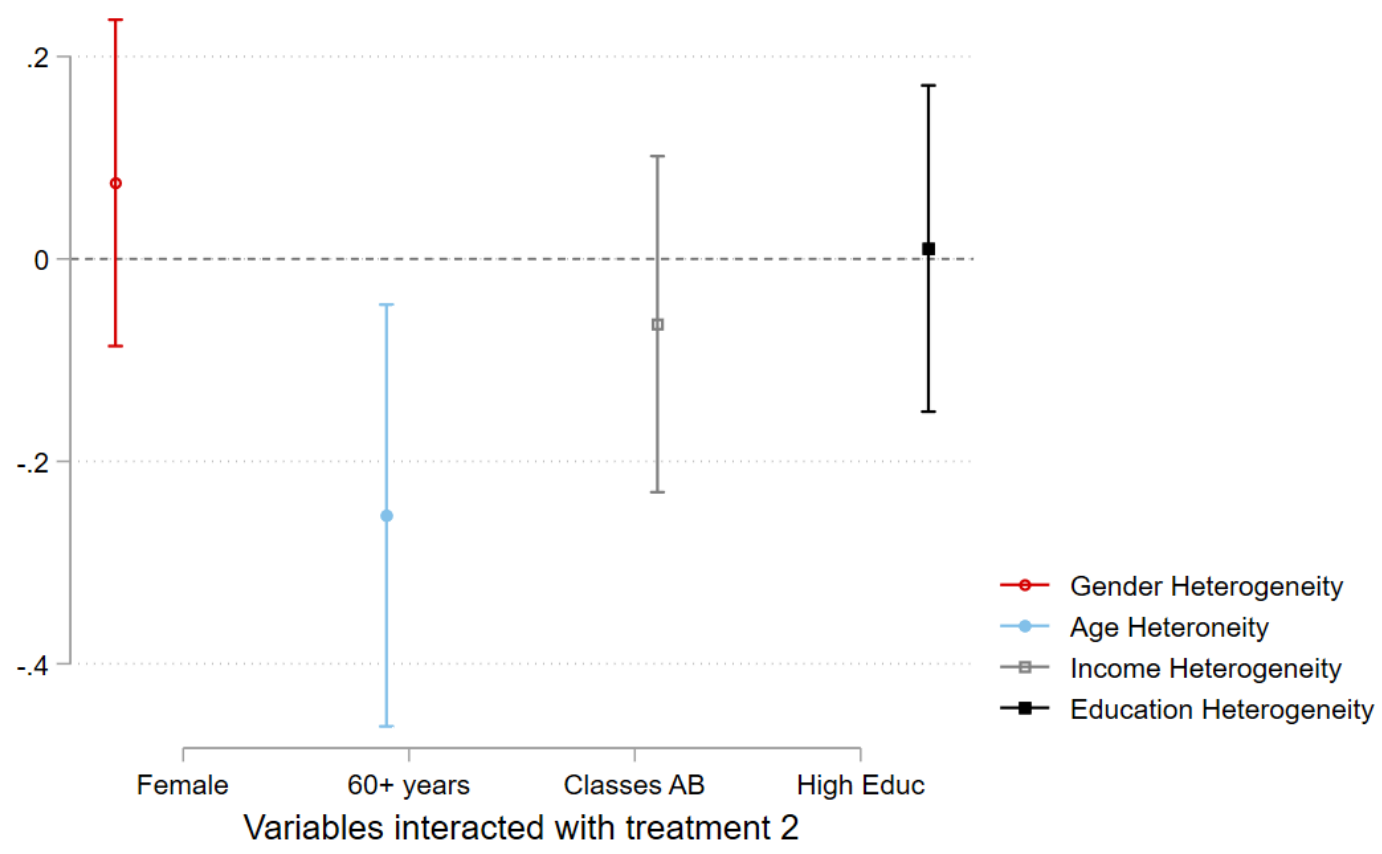

Notes. The figure shows point estimates and $95 \%$ confidence intervals. Source: Elaborated by the authors.

\section{IMPLICATIONS}

In this paper, we use a randomized survey experiment to assess how people react to different pieces of information during a pandemic crisis, when they are faced with intense governmental miscommunication. Our main results reveal that providing survey respondents with more pessimistic or more optimistic broken pieces of information regarding the pandemic has a non-significant average effect on perceptions and planned behavior. These findings suggest that, on average, Brazilians that have a profile like the average profile of survey respondents are not sensitive to fragmented information in times of governmental misinformation; rather, they stick to their perceptions and planned behavior.

The insensitivity of these Brazilian citizens to fragmented messages can be favorable when they stick to the path of moving towards the desirable direction of containing disease spread. However, this insensitivity can also be highly harmful when citizens are inflexibly moving in the opposite direction; because, in this case, it can prevent people from reacting to serious pieces of information when they actually should - for the best of everyone.

Despite the overall non-significant average treatment effects, interesting results come about when we restrict the analyses to specific sociodemographic groups. In fact, people that hold up to a high school degree and people aged 60 or older - the ones who make up the high-risk group for COVID-19 complications - seem to be more sensitive to fragmented information. Less educated individuals react to more pessimistic facts about the pandemic with a higher probability of intensifying preventive 
measures. And, people aged 60 or older, when exposed to more optimistic messages, react with a lower likelihood of intensifying their actions to prevent contamination, potentially hindering the effects of calls to stimulate social isolation.

Despite this study's limitations in terms of external validity and sample size, random assignment guarantees its internal validity. Although respondents, on average, seem not to be very sensitive to fragmented pieces of information, the causal effects found for specific sociodemographic groups highlight the importance of accurate and comprehensive communication strategies aimed at influencing both citizens' perceptions and their underlying measures to contain a national epidemic. It is suggestive that the provision of contradictory information by government officers and media vehicles can jeopardize the necessary collaborative efforts from citizens to coproduce public services, at least for some specific sociodemographic groups. Thus, relying on evidence-based recommendations and providing citizens with consistent and complete information aimed at adequately influencing their behavior can only help ease the socioeconomic side effects of a pandemic crisis, yet it may not be enough when people have already assumed an inflexible position towards the situation.

From a theoretical point of view, our work contributes to the discussion on the design of effective communication to nurture the collaborative efforts of both individuals and organizations towards a common end (Ansell \& Gash, 2018), even in settings where political rivalry prevails (Cabral \& Krane, 2018). In addition, we add to the emerging literature of disaster management in public administration (Kapucu \& Garayev, 2011; Boin \& Lodge, 2016) by raising awareness of new perspectives regarding communication in times of a pandemic. Depending on their level of sensitivity to broken messages, people may or may not react to new information stimuli, demanding an even more sophisticated communication strategy from government officers if they are to influence people to take action. 


\section{REFERENCES}

Anderson, R., Heesterbeek, H., Klinkenberg, D., \& Hollingsworth, T. (2020, March 21). How will country-based mitigation measures influence the course of the COVID-19 epidemic? The Lancet, 395(10228), 931-934. Retrieved from https://doi. org/10.1016/S0140-6736(20)30567-5

Ansell, C., \& Gash, A. (2018). Collaborative platforms as a governance strategy. Journal of Public Administration Research and Theory, 28(1), 16-32.

Boin, A., \& Lodge, M. (2016). Designing resilient institutions for transboundary crisis management: A time for public administration. Public Administration, 94(2), 289-298.

Bovaid, T. (2007). Beyond engagement and participation: User and community coproduction of public services. Public Administration Review, 67(5), 846-860.

Bursztyn, L., Egorov, G., \& Fiorin, S. (2020, March). From extreme to mainstream: The erosion of social norms. Retrieved from https://home.uchicago. edu/bursztyn/Bursztyn_Egorov_Fiorin_Extreme_ Mainstream_2020_03_26.pdf

Cabral, S., \& Krane, D. (2018). Civic festivals and collaborative governance. International Review of Administrative Sciences, 84(1), 185-205.

Chaomin Wu, M., Xiaoyan Chen, M., Yanping Cai, M., Jia’an Xia, M., Xing Zhou, M., \& Sha Xu, M. (2020, March 13). Risk Factors Associated With Acute Respiratory Distress Syndrome and Death in Patients With Coronavirus Disease 2019 Pneumonia in Wuhan, China. Jama Internal Medicine. Retrieved from https://doi.org/10.1001/ jamainternmed.2020.0994

Chong, D., \& Druckman, J. (2010, November). Dynamic Public Opinion: Communication Effects over Time. American Political Science Review, 104(4). Retrieved from https://doi.org/10.1017/ S0003055410000493

Clark, B., Brudney, J., \& Jang, S. (2013). Coproduction of government services and the new information technology: Investigating the distributional biases. Public Administration Review, 73(5), 687-701.

Coletta, R. (2020, March 24). Em pronunciamento, Bolsonaro critica fechamento de escolas, ataca governadores e culpa mídia. Folha de S. Paulo. Retrieved from https://www1.folha.uol.com.br/ poder/2020/03/em-pronunciamento-bolsonarocritica-fechamento-de-escolas-ataca-governadorese-culpa-midia.shtml

Comfort, L., Waugh, W., \& Cigler, B. (2012). Emergency management research and practice in public administration: Emergence, evolution, expansion, and future directions. Public Administration Review, 72(4), 539-547.

Correia, S., Luck, S., \& Verner, E. (2020, March 26). Pandemics Depress the Economy, Public Health Interventions Do Not: Evidence from the 1918 Flu. Retrieved from https://dx.doi.org/10.2139/ ssrn. 3561560

Greenstone, M., \& Nigam, V. (2020, March). Does Social Distancing Matter? Retrieved from https://papers.ssrn.com/sol3/papers.cfm?abstract_ id=3561244

Gross, K. (2008, February 29). Framing Persuasive Appeals: Episodic and Thematic Framing, Emotional Response, and Policy Opinion. Political Psychology, 9(2), 169-192. Retrieved from https:// doi.org/10.1111/j.1467-9221.2008.00622.x

Kapucu, N., \& Garayev, V. (2011). Collaborative decision-making in emergency and disaster management. International Journal of Public Administration, 34(6), 366-375.

McLennan, B. (2018). Conditions for effective coproduction in community-led disaster risk management. VOLUNTAS: International Journal of Voluntary and Nonprofit Organizations, 1-17.

Onder, G., Rezza, G., \& Brusaferro, S. (2020, March 23). Case-Fatality Rate and Characteristics of Patients Dying in Relation to COVID-19 in Italy. Jama Internal Medicine. Retrieved from https://doi. org/10.1001/jama.2020.4683

Shareef, M., Dwivedi, Y., Mahmud, R., Wright, A., Rahman, M., Kizgin, H., \& Rana, N. (2019). Disaster management in Bangladesh: developing an effective emergency supply chain network. Annals of Operations Research, 283(1), 1463-1487.

Walker, P., Whittaker, C., Watson, O., Baguelin, M., Ainslie, K., Bhatia, S., ... Boonyasiri, A. (2020, March 26). The Global Impact of COVID-19 and Strategies 
RAP | Pandemics and communication: an experimental assessment

for Mitigation and Suppression. London, UK: WHO Collaborating Centre for Infectious Disease Modelling, MRC Centre for Global, Infectious Disease Analysis, Abdul Latif Jameel Institute for Disease and Emergency Analytics, Imperial College London.
World Health Organization. (2020, March 19). Risk communication and community engagement readiness and response to coronavirus disease (COVID-19). Interim guidance. Retrieved from https://apps.who.int/iris/bitstream/ handle/10665/331513/WHO-2019-nCoV-RCCE2020.2-eng.pdf? sequence $=1$ \&isAllowed $=y$

\section{Carolina Melo}

https://orcid.org/0000-0003-0580-2531

Master of Public Administration and Ph.D. Candidate in Business Economics at Insper Institute of Education and Research. E-mail: carolinapgm1@insper.edu.br

\section{Sandro Cabral}

https://orcid.org/0000-0002-8663-2441

Ph.D. in Business Administration and Associate Professor at Insper Institute of Education and Research.

E-mail: sandroc2@insper.edu.br 


\section{APPENDIX}

\section{FIGURE A1 EFFECT OF TREATMENT 1 ON WORRYING}

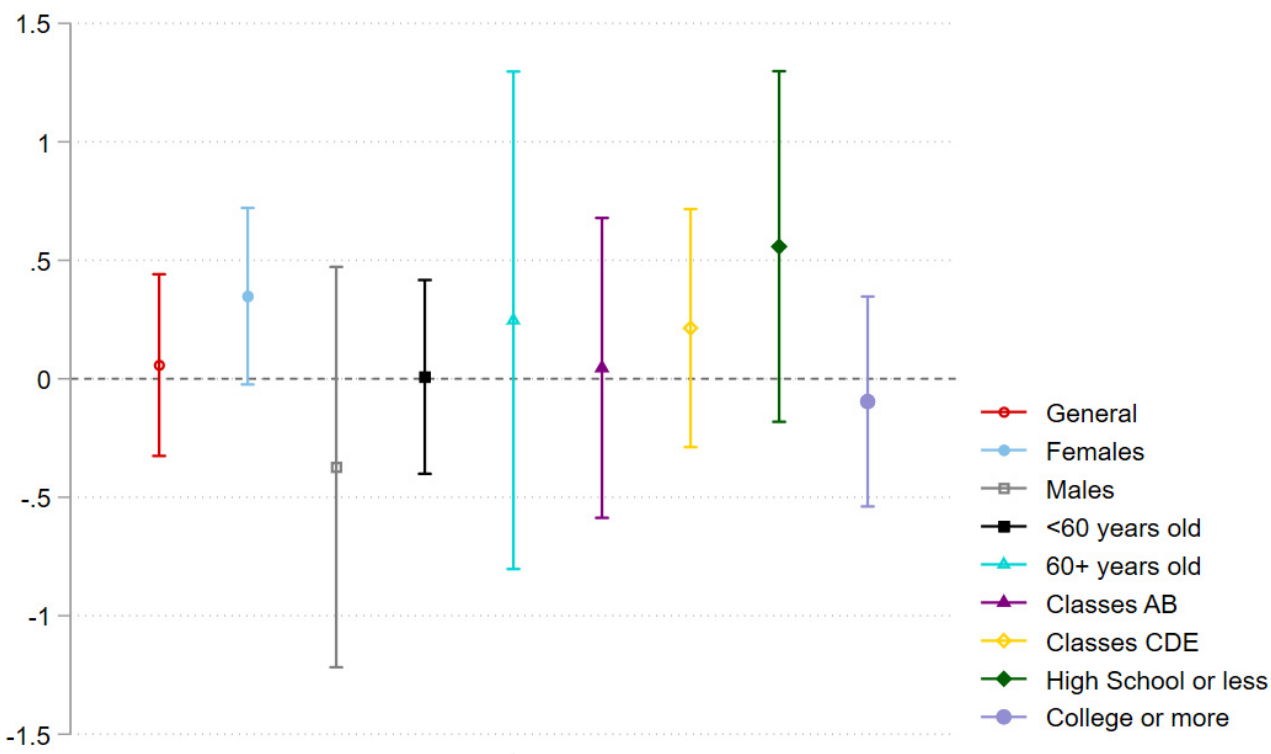

Treatment 1

Notes. The figure shows point estimates and 95\% confidence intervals. The term "general" indicates the point estimate for the unrestricted sample. Source: Elaborated by the authors.

\section{FIGURE A2 EFFECT OF TREATMENT 2 ON WORRYING}

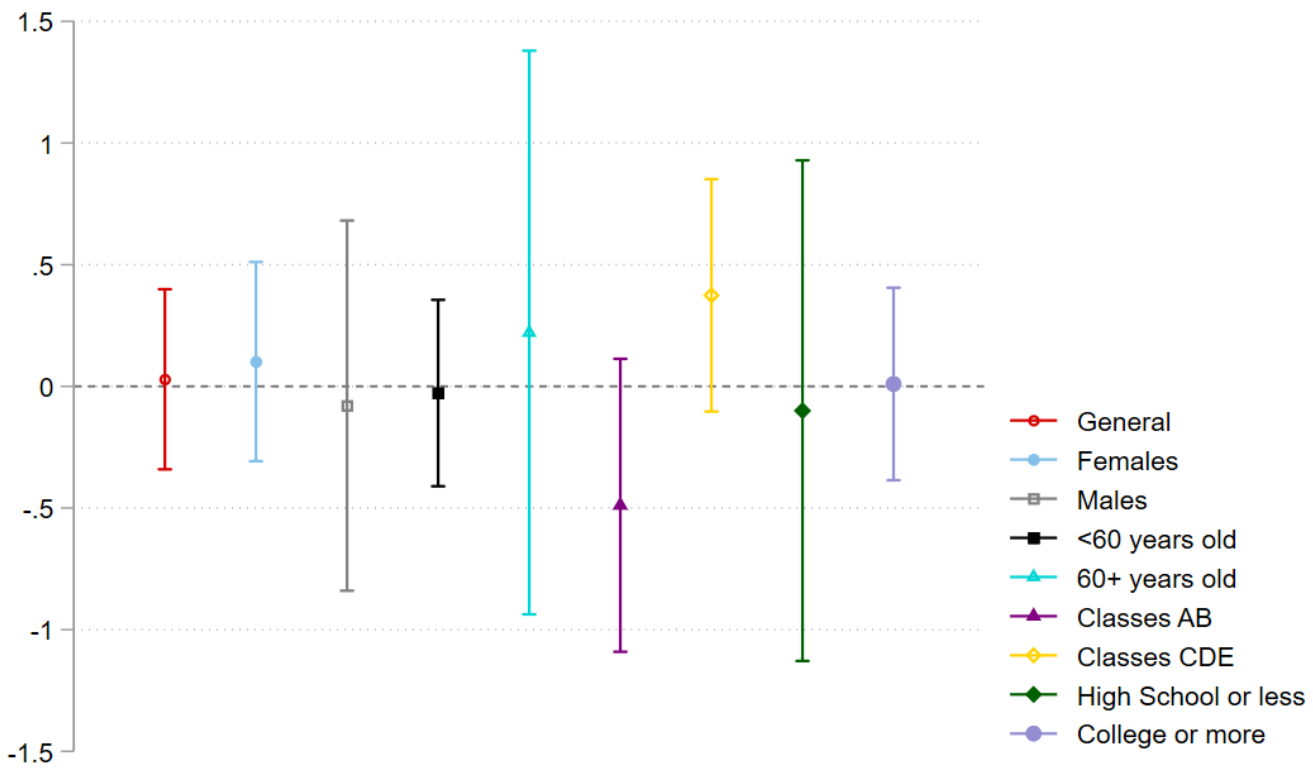

Treatment 2

Notes. The figure shows point estimates and $95 \%$ confidence intervals. The term "general" indicates the point estimate for the unrestricted sample.

Source: Elaborated by the authors. 


\section{FIGURE A3 EFFECT OF TREATMENT 1 ON EXAGGERATING}

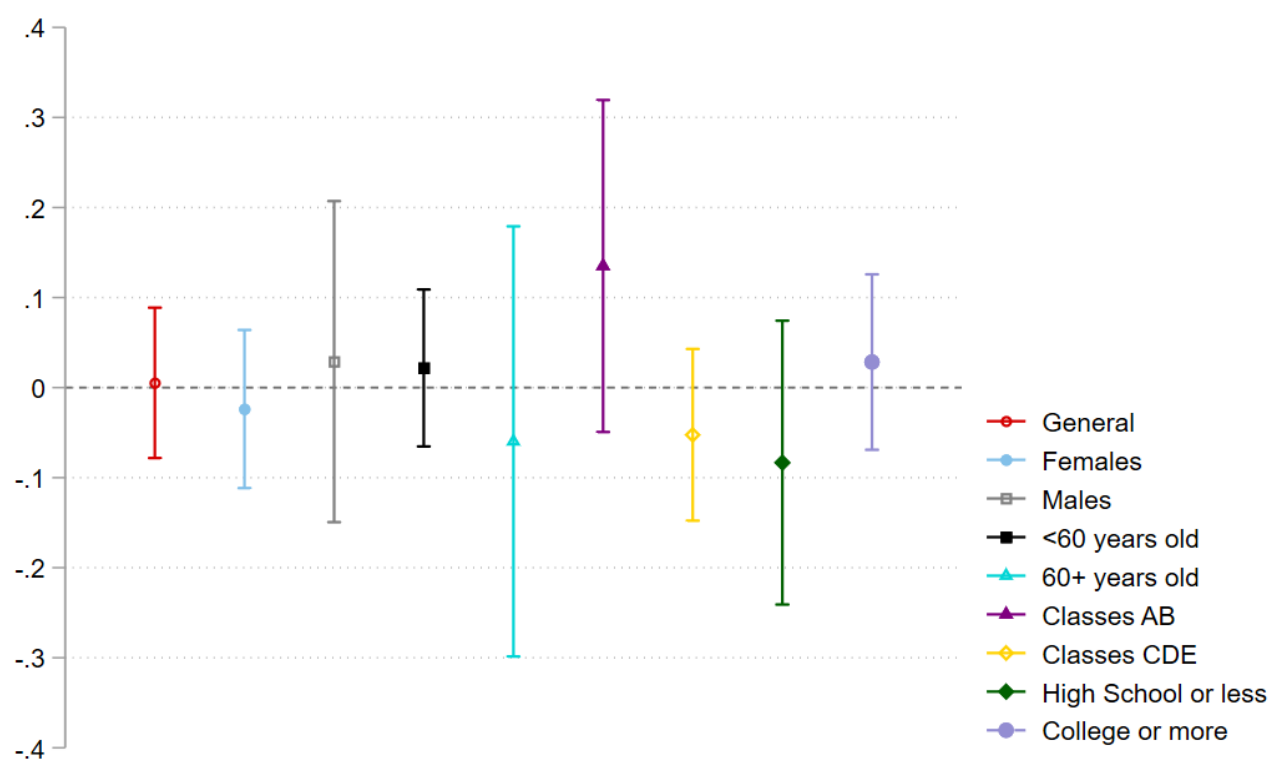

Treatment 1

Notes. The figure shows point estimates and 95\% confidence intervals. The term "general" indicates the point estimate for the unrestricted sample.

Source: Elaborated by the authors.

\section{FIGURE A4 EFFECT OF TREATMENT 2 ON EXAGGERATING}

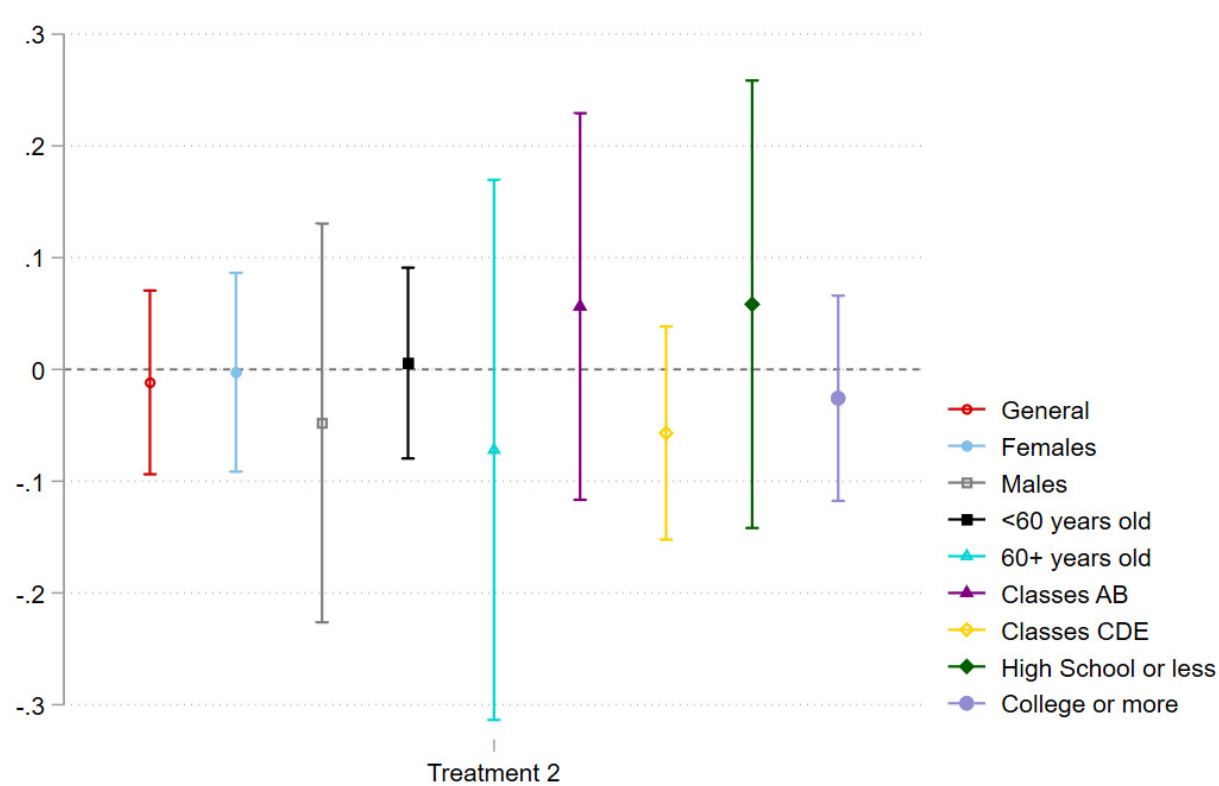

Notes. The figure shows point estimates and $95 \%$ confidence intervals. The term "general" indicates the point estimate for the unrestricted sample.

Source: Elaborated by the authors. 
RAP | Pandemics and communication: an experimental assessment

\section{TABLE A1 SUMMARY STATISTICS BY GROUP}

\begin{tabular}{|c|c|c|c|c|c|c|c|c|c|}
\hline \multirow{2}{*}{ Variable } & \multicolumn{3}{|c|}{ Treatment Group 1} & \multicolumn{3}{|c|}{ Treatment Group 2} & \multicolumn{3}{|c|}{ Control Group } \\
\hline & Mean & SD & Obs & Mean & SD & Obs & Mean & SD & Obs \\
\hline Worrying & 8.5105 & 1.8961 & 190 & 8.482 & 1.765 & 191 & 8.4526 & 1.9094 & 190 \\
\hline Exaggerating & 0.2211 & 0.4161 & 190 & 0.204 & 0.404 & 191 & 0.2158 & 0.4125 & 190 \\
\hline Intensify & 0.9158 & 0.2784 & 190 & 0.874 & 0.332 & 191 & 0.9158 & 0.2784 & 190 \\
\hline Age & 41.4526 & 15.4617 & 190 & 41.241 & 14.974 & 191 & 41.5105 & 15.4956 & 190 \\
\hline $60+$ years & 0.1632 & 0.3705 & 190 & 0.152 & 0.360 & 191 & 0.1789 & 0.3843 & 190 \\
\hline Female & 0.6632 & 0.4739 & 190 & 0.702 & 0.459 & 191 & 0.7263 & 0.4470 & 190 \\
\hline White & 0.7000 & 0.4595 & 190 & 0.696 & 0.461 & 191 & 0.6842 & 0.4661 & 190 \\
\hline Black & 0.0316 & 0.1753 & 190 & 0.063 & 0.243 & 191 & 0.0474 & 0.2130 & 190 \\
\hline Asian & 0.0263 & 0.1605 & 190 & 0.026 & 0.160 & 191 & 0.0263 & 0.1605 & 190 \\
\hline Brown & 0.2211 & 0.4161 & 190 & 0.209 & 0.408 & 191 & 0.2316 & 0.4230 & 190 \\
\hline Indigenous & 0.0000 & 0.0000 & 190 & 0.000 & 0.000 & 191 & 0.0053 & 0.0725 & 190 \\
\hline Primary School & 0.0053 & 0.0725 & 190 & 0.005 & 0.072 & 191 & 0.0105 & 0.1023 & 190 \\
\hline High School & 0.2053 & 0.4050 & 190 & 0.152 & 0.360 & 191 & 0.2421 & 0.4295 & 190 \\
\hline Undergraduate & 0.3789 & 0.4864 & 190 & 0.335 & 0.473 & 191 & 0.3684 & 0.4837 & 190 \\
\hline Graduate & 0.4105 & 0.4932 & 190 & 0.508 & 0.501 & 191 & 0.3789 & 0.4864 & 190 \\
\hline Classes AB & 0.2759 & 0.4482 & 174 & 0.305 & 0.462 & 177 & 0.2890 & 0.4546 & 173 \\
\hline
\end{tabular}

Source: Elaborated by the authors.

\section{TABLE A2 BALANCE TESTS}

\begin{tabular}{|c|c|c|c|c|c|c|c|}
\hline Variable & Treat 1 & SE & $p$-value & Treat 2 & SE & p-value & $\mathrm{N}$ \\
\hline Age & -0.0579 & 1.5881 & 0.9709 & -0.2697 & 1.5613 & 0.8629 & 571 \\
\hline $60+$ years & -0.0158 & 0.0387 & 0.6836 & -0.0271 & 0.0381 & 0.4775 & 571 \\
\hline Female & -0.0632 & 0.0473 & 0.1820 & -0.0247 & 0.0464 & 0.5941 & 571 \\
\hline White & 0.0158 & 0.0475 & 0.7396 & 0.0121 & 0.0475 & 0.7986 & 571 \\
\hline Black & -0.0158 & 0.0200 & 0.4305 & 0.0155 & 0.0234 & 0.5095 & 571 \\
\hline
\end{tabular}


RAP | Pandemics and communication: an experimental assessment

\begin{tabular}{lcccccccc}
\hline Variable & Treat 1 & SE & p-value & Treat 2 & SE & p-value & N \\
\hline Asian & 0.0000 & 0.0165 & 1.0000 & -0.0001 & 0.0164 & 0.9933 & 571 \\
Brown & -0.0105 & 0.0430 & 0.8069 & -0.0222 & 0.0426 & 0.6030 & 571 & 571 \\
Indigenous & -0.0053 & 0.0053 & 0.3177 & -0.0053 & 0.0053 & 0.3177 & 571 \\
Primary School & -0.0053 & 0.0091 & 0.5632 & -0.0053 & 0.0091 & 0.5605 & 571 \\
\hline High School & -0.0368 & 0.0428 & 0.3900 & -0.0903 & 0.0406 & 0.0266 & 571 \\
Undergraduate & 0.0105 & 0.0498 & 0.8325 & -0.0333 & 0.0490 & 0.4967 & 571 \\
Graduate & 0.0316 & 0.0503 & 0.5300 & 0.1289 & 0.0506 & 0.0111 & 571 \\
Classes AB & -0.0132 & 0.0485 & 0.7862 & 0.0161 & 0.0490 & 0.7430 & 524 \\
\hline
\end{tabular}

Notes. Balance tests were performed using regression equation (1) with sociodemographic variables as dependent variables. Standard errors are robust.

Source: Elaborated by the authors.

\section{TABLE A3 TREATMENT EFFECTS FOR PEOPLE THAT HOLD UP TO A HIGH SCHOOL DEGREE}

\begin{tabular}{|c|c|c|c|c|c|c|}
\hline & (1) & (2) & (3) & (4) & (5) & (6) \\
\hline Variable & Worrying & Worrying & Exaggerating & Exaggerating & Intensify & Intensify \\
\hline Treat 1 & 0.5583 & 0.4865 & -0.0833 & -0.0556 & 0.0833 & 0.0840 \\
\hline SE & 0.3735 & 0.4016 & 0.0796 & 0.0889 & 0.0404 & 0.0564 \\
\hline$p$-value & 0.1377 & 0.2290 & 0.2972 & 0.5330 & 0.0414 & 0.1398 \\
\hline Treat 2 & -0.1000 & -0.2889 & 0.0583 & 0.0250 & -0.0500 & -0.0581 \\
\hline SE & 0.5194 & 0.6195 & 0.1011 & 0.1107 & 0.0747 & 0.0811 \\
\hline$p$-value & 0.8477 & 0.6422 & 0.5649 & 0.8219 & 0.5048 & 0.4758 \\
\hline Constant & 8.1667 & 13.3564 & 0.2083 & 0.3736 & 0.9167 & 1.2663 \\
\hline SE & 0.3034 & 1.6430 & 0.0594 & 0.3062 & 0.0404 & 0.1769 \\
\hline$p$-value & 0.0000 & 0.0000 & 0.0006 & 0.2257 & 0.0000 & 0.0000 \\
\hline $\mathrm{N}$ & 118 & 106 & 118 & 106 & 118 & 106 \\
\hline Controls & NO & YES & NO & YES & NO & YES \\
\hline
\end{tabular}

Notes. Estimations performed using regression equation (1). Set of control variables include all sociodemographic characteristics collected in the survey, except for education level. Standard errors are robust.

Source: Elaborated by the authors. 


\section{TABLE A4 TREATMENT EFFECTS FOR PEOPLE AGED 60 OR OLDER}

\begin{tabular}{lcccccc} 
& $(\mathbf{1})$ & $(\mathbf{2})$ & $(3)$ & $(4)$ & $(5)$ & $(6)$ \\
Variable & Worrying & Worrying & Exaggerating & Exaggerating & Intensify & Intensify \\
\hline Treat 1 & 0.2467 & 0.2725 & -0.0598 & -0.0650 & 0.0237 & 0.0931 \\
SE & 0.5285 & 0.5730 & 0.1202 & 0.1346 & 0.0667 & 0.0848 \\
p-value & 0.6418 & 0.6360 & 0.6203 & 0.6306 & 0.7231 & 0.2766 \\
Treat 2 & 0.2211 & 0.1116 & -0.0720 & -0.1161 & -0.2566 & -0.2264 \\
SE & 0.5830 & 0.6893 & 0.1216 & 0.1260 & 0.1024 & 0.1203 \\
p-value & 0.7054 & 0.8719 & 0.5554 & 0.3604 & 0.0140 & 0.0644 \\
Constant & 7.8824 & 9.1066 & 0.3824 & -0.4597 & 0.9118 & -0.0481 \\
SE & 0.3506 & 4.8030 & 0.0847 & 0.9388 & 0.0494 & 0.6013 \\
p-value & 0.0000 & 0.0625 & 0.0000 & 0.6260 & 0.0000 & 0.9365 \\
N & 94 & 85 & 94 & 85 & 94 & 85 \\
Controls & NO & YES & NO & YES & NO & YES
\end{tabular}

Notes. Estimations performed using regression equation (1). Set of control variables include all sociodemographic characteristics collected in the survey, except for age. Standard errors are robust.

Source: Elaborated by the authors.

\section{TABLE A5 HETEROGENEOUS TREATMENT EFFECTS - LEAST-EDUCATED VS. MOST-EDUCATED}

\begin{tabular}{lccc} 
& \multicolumn{1}{c}{$(\mathbf{1})$} & $(\mathbf{2})$ & $(3)$ \\
\hline Variable & Worrying & Exaggerating & Intensify \\
\hline Treat 1 & 0.5583 & -0.0833 & 0.0833 \\
\hline SE & 0.3706 & 0.0790 & 0.0401 \\
\hline p-value & 0.1325 & 0.2917 & 0.0382 \\
Treat 2 & -0.1000 & 0.0583 & -0.0500 \\
SE & 0.5154 & 0.1003 & 0.0742 \\
p-value & 0.8462 & 0.5611 & 0.5005 \\
High Educ & 0.3826 & 0.0100 & -0.0012 \\
SE & 0.3385 & 0.0685 & 0.0465 \\
p-value & 0.2588 & 0.8842 & 0.9799 \\
Treat 1*High Educ & -0.6543 & 0.1117 & -0.1055 \\
SE & 0.4340 & 0.0933 & 0.0529 \\
\hline
\end{tabular}


RAP | Pandemics and communication: an experimental assessment

\begin{tabular}{lccc} 
& (1) & $(\mathbf{2})$ & $(3)$ \\
\hline Variable & Worrying & Exaggerating & Intensify \\
\hline p-value & 0.1322 & 0.2317 & 0.0467 \\
Treat 2*High Educ & 0.1097 & -0.0841 & 0.0103 \\
SE & 0.5535 & 0.1107 & 0.0821 \\
p-value & 0.8429 & 0.4477 & 0.9003 \\
Constant & 8.1667 & 0.2083 & 0.9167 \\
SE & 0.3011 & 0.0589 & 0.0401 \\
p-value & 0.0000 & 0.0004 & 0.0000 \\
N & 571 & 571 & 571 \\
\hline
\end{tabular}

Notes. Estimations performed using regression equation (2). High Educ is a dummy variable that takes the value of 1 if the highest level of education the person completed is either an undergraduate or a graduate degree, and the value of 0 if the highest degree completed is up to a high school degree. Standard errors are robust.

Source: Elaborated by the authors.

\section{TABLE A6 HETEROGENEOUS TREATMENT EFFECTS - YOUNG VS. OLD}

\begin{tabular}{lccc} 
& $(\mathbf{1})$ & $(\mathbf{2})$ & $(3)$ \\
\hline Variable & Worrying & Exaggerating & Intensify \\
\hline Treat 1 & 0.0080 & 0.0218 & -0.0047 \\
\hline SE & 0.2085 & 0.0445 & 0.0317 \\
p-value & 0.9695 & 0.6245 & 0.8818 \\
Treat 2 & -0.0275 & 0.0057 & -0.0031 \\
SE & 0.1953 & 0.0435 & 0.0314 \\
\hline -value & 0.8879 & 0.8959 & 0.9218 \\
Old & -0.6946 & 0.2029 & -0.0049 \\
SE & 0.3776 & 0.0893 & 0.0537 \\
\hline -value & 0.0664 & 0.0235 & 0.9273 \\
Treat $1^{*}$ Old & 0.2387 & -0.0815 & 0.0284 \\
SE & 0.5628 & 0.1270 & 0.0732 \\
\hline$p$-value & 0.6716 & 0.5210 & 0.6980 \\
\hline
\end{tabular}


RAP | Pandemics and communication: an experimental assessment

\begin{tabular}{lccc} 
& (1) & (2) & $(3)$ \\
\hline Variable & Worrying & Exaggerating & Intensify \\
\hline Treat 2*0ld & 0.2486 & -0.0777 & -0.2535 \\
\hline SE & 0.6088 & 0.1280 & 0.1061 \\
\hline p-value & 0.6832 & 0.5439 & 0.0172 \\
Constant & 8.5769 & 0.1795 & 0.9167 \\
SE & 0.1495 & 0.0309 & 0.0222 \\
\hline p-value & 0.0000 & 0.0000 & 0.0000 \\
$N$ & 571 & 571 & 571 \\
\hline
\end{tabular}

Notes. Estimations performed using regression equation (2). Old is a dummy variable that takes the value of 1 if the person is aged 60 or older and the value of 0 otherwise. Standard errors are robust. Source: Elaborated by the authors. 